\title{
A GIS Based Assessment of a Dynamic Watershed in Guam
}

\author{
Sydonia Manibusan ${ }^{1}$, Shahram Khosrowpanah ${ }^{2}$, Mark Alan Lander ${ }^{1}$, Mohammad Golabi ${ }^{3}$, \\ Ujwalkumar Dashrath Patil ${ }^{2, *}$
}

\author{
${ }^{1}$ Water and Environmental Research Institute, University of Guam, Mangilao, Guam \\ ${ }^{2}$ School of Engineering, University of Guam, Mangilao, Guam \\ ${ }^{3}$ College of Natural and Applied Sciences, University of Guam, Mangilao, Guam
}

\section{Email address:}

patilu@ triton.uog.edu (U. D. Patil)

${ }^{*}$ Corresponding author

\section{To cite this article:}

Sydonia Manibusan, Shahram Khosrowpanah, Mark Alan Lander, Mohammad Golabi, Ujwalkumar Dashrath Patil. A GIS Based Assessment of a Dynamic Watershed in Guam. Hydrology. Vol. 7, No. 1, 2019, pp. 1-9. doi: 10.11648/j.hyd.20190701.11

Received: December 26, 2018; Accepted: January 14, 2019; Published: January 31, 2019

\begin{abstract}
This paper presents an analysis of the potential impact of existing and proposed natural and human activities on the behavior of existing watershed and suggests recommendations to effectively manage such activities to reduce the detrimental impacts on the watershed. The hydrologic behavior of the Piti-Asan watershed in Guam was analyzed through the field measurements of rainfall, stream level, stream flow, and river turbidity over the course of one year. Estimates of the erosion contribution by areas within the watershed and in particular, within 100-meter buffer zone around the major rivers were conducted based on the data collected via field instrumentation and using the geographic information system (GIS) based erosion model. Stage discharge curves were obtained for both watersheds from analyses of field hydrologic data. In addition, the areas contributing the most potential erosion and the major causes of soil erosion in the Piti-Asan watershed were identified. Finally, best management strategies of the watershed system to aid in maximizing the effectiveness and viability of future restoration efforts were suggested.
\end{abstract}

Keywords: Watershed, GIS-Based Erosion Model, Turbidity, Stage Discharge Curve, Watershed Management Practices

\section{Introduction}

A dynamic relationship exists between the water bodies (i.e., rivers, streams, lakes) and the surrounding landscape. Very often, this relationship can be sensitive in case of islands formed from volcanic eruptions and uplift of seabed, especially due to the typical characteristics of landscape such as the mountainous terrain receiving large amount of rainfall from typhoon events. Heavy rainfall and typhoon events result in extensive runoff that carries excessive sedimentation due to erosion and loss of landcover which ultimately ends up in water bodies. Worldwide, 24 billion tons of soil is lost annually, which makes it a sustainability issue [1]. In addition, continuous human interactions, i.e., construction [2], mining [3], burning grass [4] keep impacting these dynamic systems, thereby adversely affecting the quality of water. Previous investigations had concluded that the complex interaction of fire, vegetation, erosion and sedimentation has been poorly investigated on Guam [5].
Piti-Asan watershed lies southeast of the Pago-Adelup fault, which divides the northern limestone and the southern volcanic uplands of Guam (Figures 1-2). The Nature Conservancy [6] created a Draft Conservation Action Plan with the aim in the village of Piti in Guam Island to become a model of a "community based, management driven, and environmentally friendly village with sustainable resources in harmony with the environment." The above-mentioned plan is part of an effort to: preserve and enhance water quality, native forest, coral reef ecosystem, and endangered species in the Piti watershed. The plan includes an analysis of conservation targets, current condition, ranked threats, potential strategies, and a capacity assessment in order to better direct efforts to improve conservation and reduce human impacts on the natural environment [6].

The existing construction is expected to increase along with increasing population and will have an adverse impact (i.e. increased sedimentation, increased risk of contamination, changes in stream flow) on the dynamic 
behavior of the Piti-Asan watershed [7]. Furthermore, the sediment and other material carried to the Piti and Asan Bay outlets from the watershed can adversely affect coastal and marine communities from the resulting decline in water quality [8]. As such the Piti-Asan watershed qualifies to be an excellent example of a dynamic watershed, which is the focus of this research to further establish best watershed management practices.

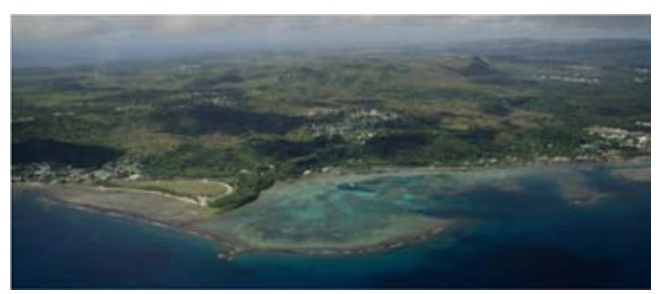

Figure 1. Aerial image of Piti-Asan watershed in Guam.

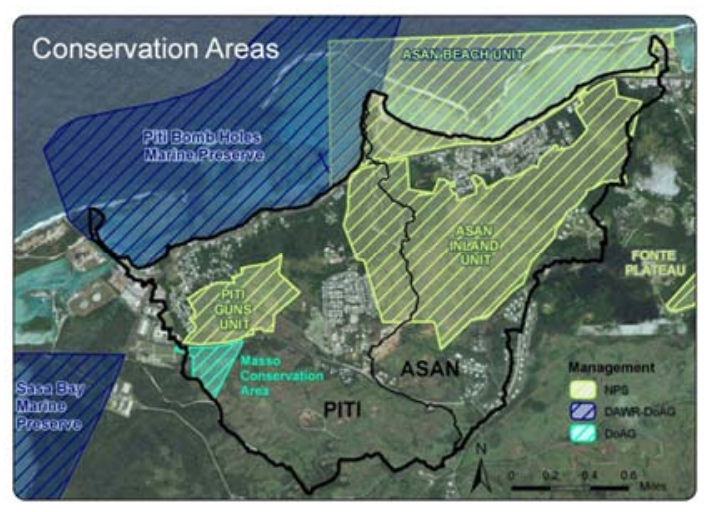

(a)

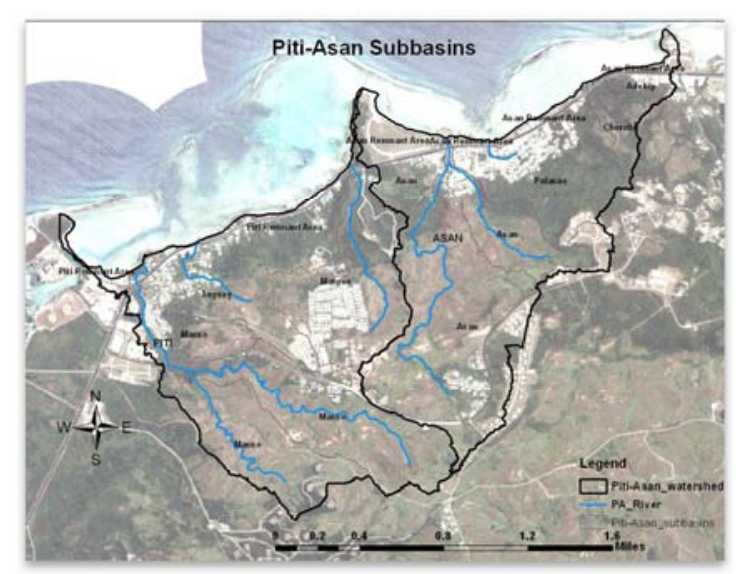

(b)

Figure 2. Piti-Asan watershed (a) conservation areas; and (b) Subbasins [8].

The topography of the Piti- Asan Watershed vary in elevation from sea level to 729 feet above sea level with slopes less than $15 \%$ along the coastal plain but is steeper along the hillside. About $36 \%$ of the watershed have slopes greater than $30 \%$ [7-8]. The coastal plain of the watershed consists primarily of alluvium and beach deposits. The lower portion of the watershed consists of Mariana limestone while the higher elevations in the northeast are covered by Alifan limestone. The northeastern area of Nimitz Hill also contains many cave features, namely "fissures, sinkholes, pits, and shelter caves" [9]. Each of the conservation areas located within the Piti-Asan Watershed feature some recreational activities. These facilities are normally used by both locals and tourists.

The Piti-Asan watershed consists of two sub-watersheds: the Piti watershed outlets flow into the Piti bay and the Asan watershed flows directly into the Asan bay. Furthermore, the watershed is divided into several sub-basins identified in Figure 2b. These sub-basins collect runoff, which is deposited into their respective rivers [7-8]. The major contributors of runoff to the Piti-Asan watershed are the Asan river in the Asan sub-basin of the Asan sub-watershed and the Masso river in the Masso sub-basin of the Piti sub-watershed and they are the focus of the hydrological study in this research.

The primary objective of this research paper is to investigate the dynamic behavior of the Piti- Asan watershed under different scenarios. Hydrologic data were collected and combined with existing current and historical data pertaining to the Piti-Asan Watershed was modeled using the geographic information system (GIS) based erosion model [10] in order to understand the existing behavior of the watershed and to predict potential future behavior of the watershed based on proposed and existing development and natural watershed activity. The collected data and model predictions will allow future prediction of the watershed behavior based upon the various proposed activities. Using this knowledge, management strategies have been developed and suggested to prevent damage to the watershed.

\section{Methods}

\subsection{Field Observations}

The most common soil types along the Asan-Piti watershed are the Agfayan-Akina and Akina-Badland complexes. The side slopes and ridge tops consist of Agfayan and Akina soils, whereas flat areas consist of Inarajan type soils. The lower elevated areas of the watershed, which are underlain by limestone, consist of Pulantat clay and Ritidianoutcrop soils [11].

Akina-Agfayan complex contains very shallow to very deep, well drained, moderately steep to extremely steep soils; on strongly dissected mountains and plateaus [11]. The Inarajan soils are often deep and very deep, somewhat poorly drained, level and nearly level soils; on valley bottoms and coastal plains. The Inarajan variant is found "in the major valleys in the central and southern parts of Guam. It is also on coastal plains along the southern coast and extends from Agat to Piti on the western coast. Pulantat clay is characterized by shallow, well drained, gently sloping to steep soils; on dissected plateaus and hills. They are composed of clay and silty clay over argillaceous limestone. Ritidian-rock outcrop soils are very shallow, well drained, 
gently sloping to extremely steep soils, and Rock outcrop; on plateaus, mountains, and escarpments [11].

The Piti-Asan watershed area is dominated by forest and savanna, which covers roughly two-thirds of the watershed as represented in Figure 6 [8]. Roughly 21 percent of the watershed is developed, about half of which are comprised of impervious material. About eight percent consists of scrub and shrub vegetation and about one percent consists of wetland vegetation. The remaining two percent consists of bare land. Various land uses, existing today include residential housing, conservation areas, commercial properties, and recreational facilities. Currently vacant private lots are also likely to be developed in the future.

\subsection{Aerial Photogrammetry}

Aerial photographs were taken to assess the land cover and vegetation of the watershed. Aerial images were taken onboard a Cessna aircraft using a digital single lens reflex (DSLR) camera during both the wet and dry seasons [7]. Photos were also used to observe high erosion points and provide a better understanding of the overall vegetative cover of the watershed area.

\subsection{Hydrologic Data}

Hydrologic data including turbidity, rainfall level, and stream level data were gathered in the two primary stream outlets, the Asan river and the Masso river (Figure 3) within the Piti-Asan watershed area to develop a correlation with the amount of rainfall, stream water level, stream flow, and water turbidity. This correlation will assist in improving the understanding of the watershed's dynamic behavior through understanding the interaction between rainfall rates with stream output and sedimentation. An understanding of this correlation will aid in predicting future watershed behavior based upon projected development activities within the watershed. In the collection of hydrologic data two rain gauges and four level loggers were installed throughout the Piti-Asan watershed for the duration of the one-year study. Installation and collection of hydrologic data began on June 6, 2011 and continued through June 20, 2012. Stream flow measurements and turbidity sample collection was also performed at the fixed level logger locations (Figure 3).

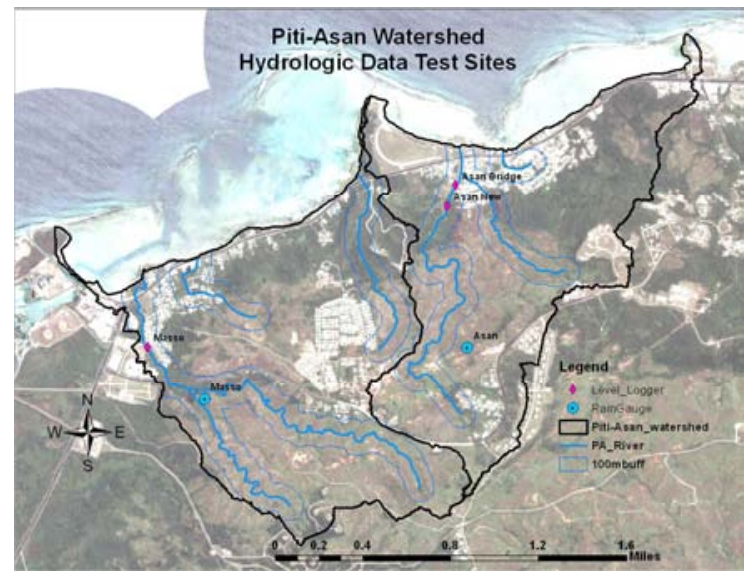

Figure 3. Hydrologic data sampling sites in Piti-Asan watershed. 2.2.1.
Rainfall measurements.

Rainfall was measured using two tipping bucket HoboWare ${ }^{\circledR}$ data logging rain gauges (Figure 4a). The rain gauges were placed at two randomly selected sites around the Piti-Asan watershed. Site selection criteria included areas which were unobstructed by large vegetation, buildings, or any other large obstructions that could block rainfall to the rain gauges. Rain gauge sites were also chosen based on ease of access to the site and the risk of damage to the rain gauge by human activity.

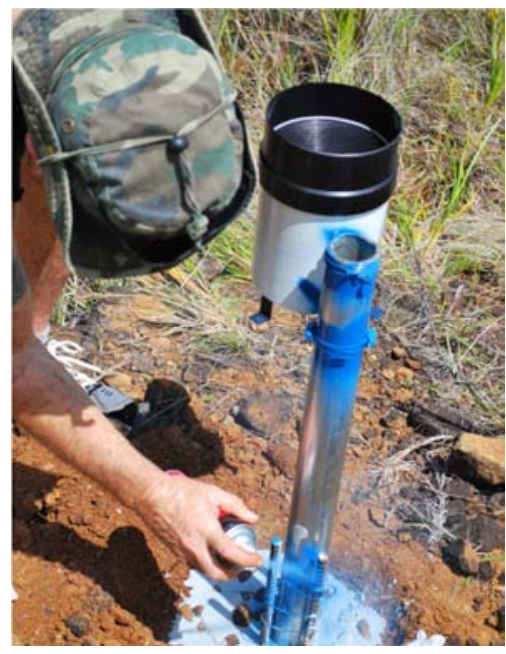

(a)

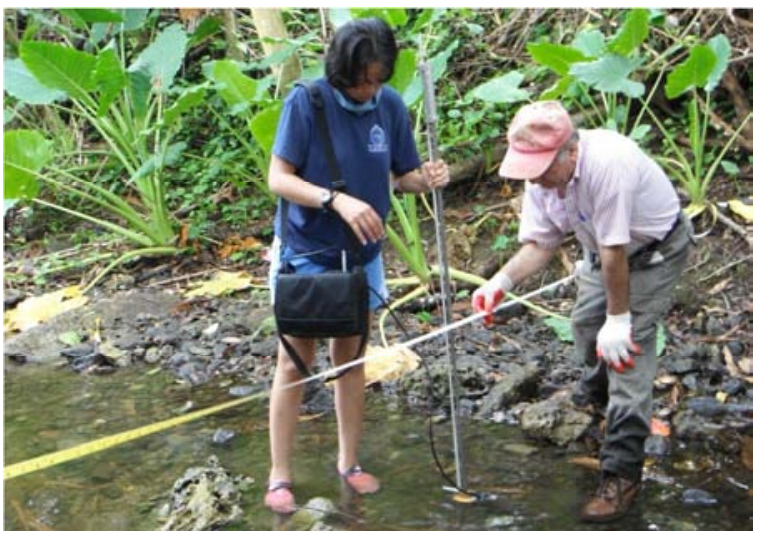

(b)

Figure 4. (a) Installation of rain gauge station at a site in Piti-Asan watershed; and (b) Stream flow measurements in Masso river.

\subsubsection{Flow Rate Measurements}

Weekly measurements of flow in the Masso (Figure 4b) and Asan rivers was conducted using an electronic flow meter. Flow measurements were taken along transects running perpendicular to the flow direction at 0.5 -foot increments from edge to edge of the river. Flow rate calculations included distance from the edge of the river, depth, and velocity as well as indications of the edge positions. The data was later input into a spreadsheet program, which calculated the flow output of the river based on the area and velocity measured at each increment. 


\subsubsection{Turbidity Measurements}

The turbidimeter is a device which measures the transmission of light reflected by particles through a solution and is an indicator of sediment in streams. Turbidity was measured using an OMEGA ${ }^{\circledR}$ handheld turbidimeter. Biweekly turbidity measurements were made from water samples taken at the Masso River and Asan River. Stream turbidity is a measure of the cloudiness of the water in terms of Nephelometric Turbidity Units (NTU), which indicates the amount of sediment carried in the stream

\subsubsection{Stream Level Measurements}

Water level was measured using four level loggers with one logger placed in each river to measure water pressure and one logger placed above the water surface and in the proximity of each river logger to measure the atmospheric pressure. The water level was measured regularly at 15minute intervals using the two-level loggers in the streams within the watershed. The recorded pressure of the in-stream loggers was compared against level loggers on land which measured atmospheric pressure. The atmospheric pressure was subtracted from the in-stream pressure to accurately calculate the water level of the streams based on pressure and temperature of the water level on the logger.

\subsection{Soil Analyses}

Soil composite samples were taken (Figure 5a-b) and tested in the lab to identify the various soil types represented in the Piti-Asan Watershed. A total of 17 composites were taken at the sites identified in Figure $6 \mathrm{~b}$, which sampled the soil from depths of zero through 36 centimeters. Composite samples were ground and sifted through a two-millimeter standard sieve and analyzed for $\mathrm{pH}$, texture, nutrients, and organic matter. All soil testing methodology was derived from the Methods of Soil analysis: chemical and microbiological properties text by [12]. This methodology has been adapted for use on Guam soils by the University of Guam's Soil Research and Testing Laboratory.

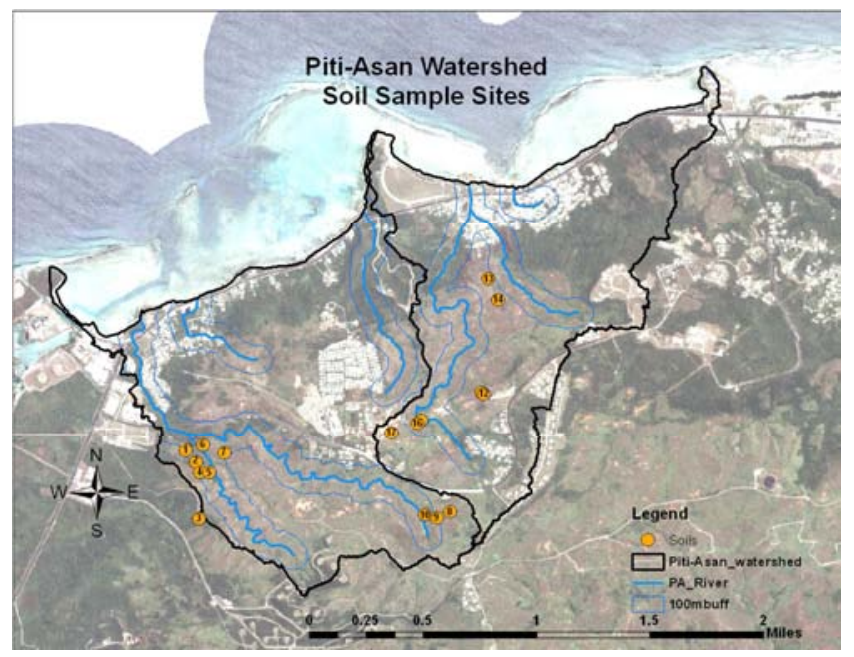

(a)

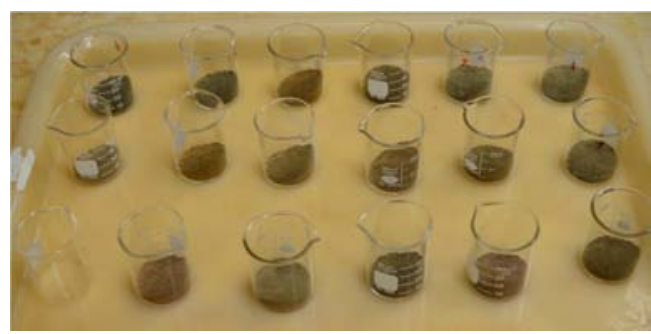

(b)

Figure 5. (a) Soil sampling sites in Piti-Asan watershed; and (b) Soil samples collected for testing.

\subsection{Estimation of Soil Loss Using GIS-USLE Model}

The GIS-USLE model can measure the annual soil loss over a given area through combining geographic information systems (GIS) with the revised universal soil loss equation (RUSLE) [10]. The RUSLE is a revised version of the original Universal Soil Loss Equation (USLE), which was developed by [13]. The GIS-USLE model was used to locate areas within the Piti- Asan watershed that contribute high levels of soil erosion and therefore detect significant areas of concern for implementing soil erosion practices. The USLE formula is described by acceptable soil loss (A), which is measured in tons/acre/year (Equation 1) and includes various parameters including rainfall erosivity factor (R) that accounts for the erosive power of rainfall, soil erodibility factor $(\mathrm{K})$ indicating the soil-loss rate for a given soil type, slope length factor $(\mathrm{L})$ which is a ratio given the input of the erosivity over the length of a slope, slope steepness factor (S) indicating the ratio of soil loss for given slope, vegetative cover factor (C) that accounts for the soil loss based on vegetative cover of the plot, and erosion control support practices factor $(\mathrm{P})$ accounts for support practices that can be used to minimize soil loss on a plot such as through terracing, contour farming, strip cropping, or no-till farming.

$$
A=R \times K \times L S \times C \times P
$$

Combined with GIS, the RUSLE is able to predict more quickly and accurately over a given area than through using the equations alone. GIS is used mainly to process and display data that contains a spatial component. In this research we have used vector and raster file formats. Vector file data contains features defined by a point, line, or polygon and are useful for storing and representing discrete features such as buildings and roads. Raster file data are composed of a rectangular matrix of cells [14-15]. The cells contain a specific width and height that is representative of a portion of the entire area of the raster as well as a value which represents the phenomenon portrayed by the raster data set, such as category, magnitude, distance, or spectral value [1415]. USLE is represented in GIS through individual raster layers of for each of the USLE factors. Because of the overlap of the raster files and grid cells in each layer, the USLE can be computed by multiplying the USLE factors [14-15]. 


\section{Results}

\subsection{Hydraulic Data}

The hydrologic data including including the rainfall collected for each watershed, stream level measured at 15minute intervals, and the biweekly turbidity measurements gathered in the course of the study from the Masso and Asan Rivers are shown in Figure 6 and 7 respectively. Figure 8 show the 15-minute rain and stream levels of both the rivers during a single storm event. These figures clearly display the reaction time of water level to changes in rainfall.

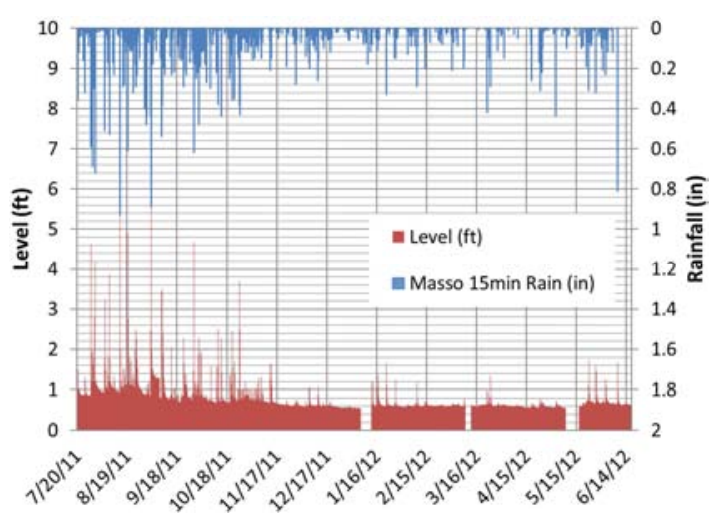

(a)

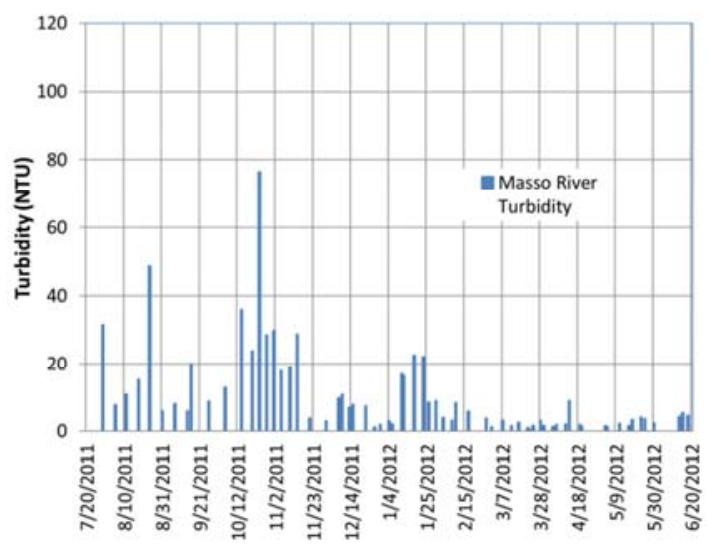

(b)

Figure 6. (a) 15-minute rainfall, river level, and (b) turbidity to the Masso River in Piti-watershed.

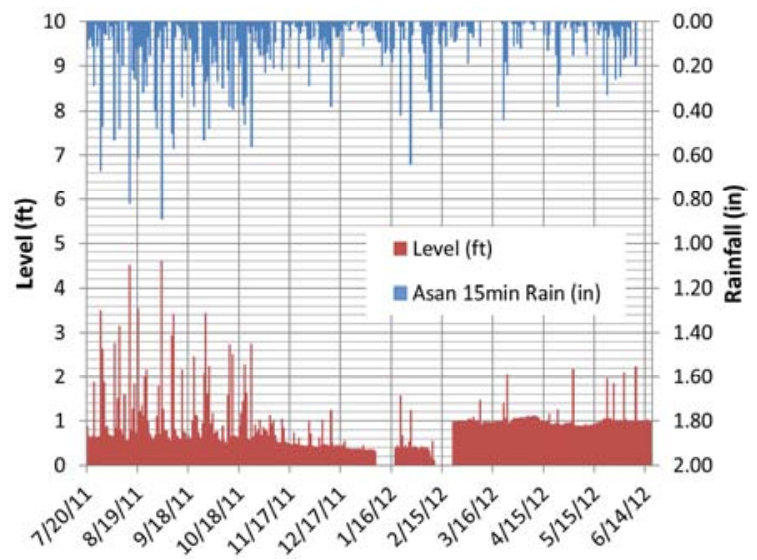

(a)

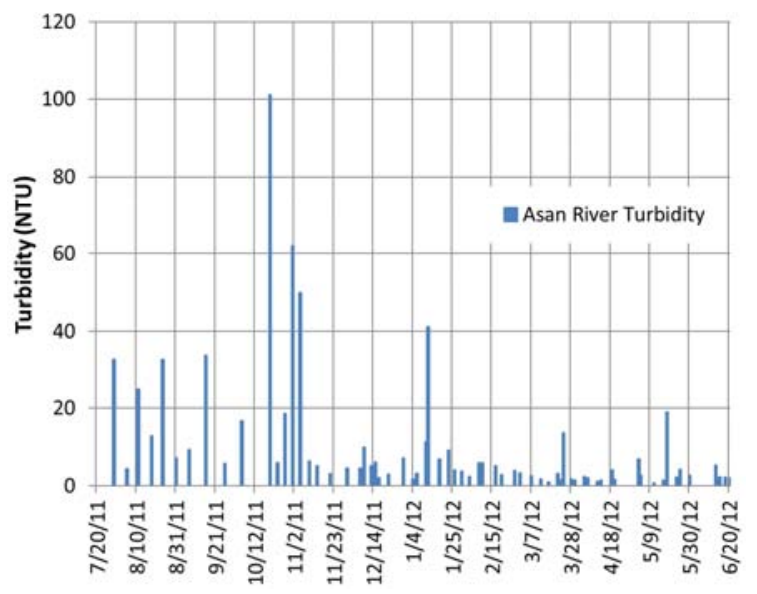

(b)

Figure 7. (a) 15-minute rainfall, river level, and (b) turbidity to the Asan River.

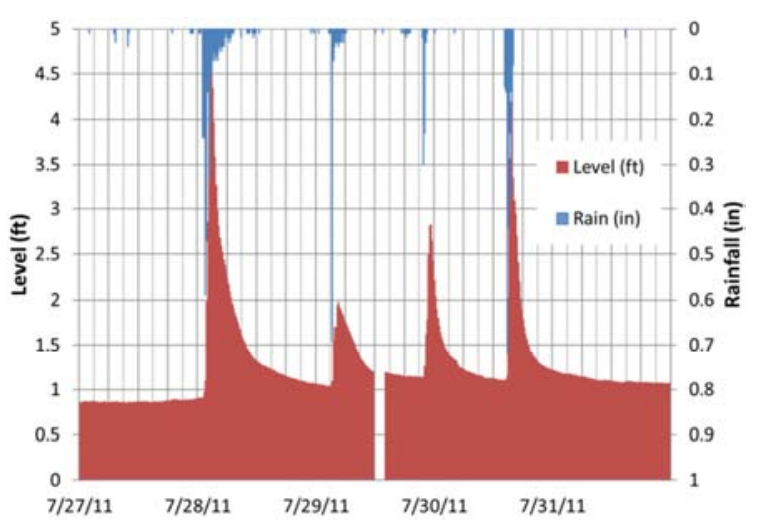

(a)

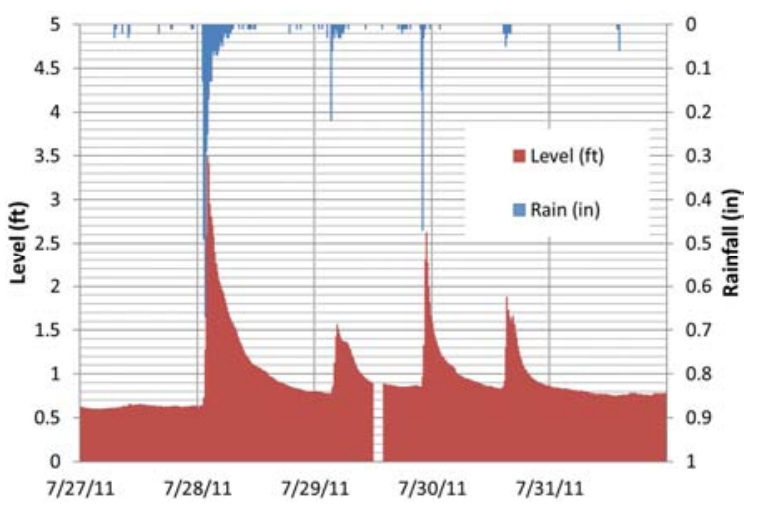

(b)

Figure 8. Storm events for (a) Masso river, and for (b) Asan river.

Figure 8a illustrates the reaction time of the Masso River's peak water level during storm events indicating that it occurred within 45 minutes of the peak rainfall during large rainfall events when compared at 15-minute intervals. On the other hand, Figure $8 \mathrm{~b}$ indicates that the Asan River's reaction time has occurred within 30 minutes of peak rainfall during major storm events. This clearly indicates that the water level of the Asan River is more reactive to rainfall events.

It should be noted that there was a gap in the rainfall data collected for the Piti-Asan Watershed (Figures 6-7) between 
August 19, 2011 and September 2, 2011, which occurred due to technical issues with the rain gauge shuttle. Rainfall data for this period was substituted using the National Weather Service's nearby weather station for that time period. Unfortunately, the largest rainfall event of the year recorded by the National Weather Service also coincided within that data gap.

In order to understand the amount of turbidity found within the rivers over time, a turbidity exceedance curve (Figure 9) was created. Figure 9 measures the percent of time that turbidity was equaled or exceeded for the given river. The measure at $100 \%$ therefore indicates the base turbidity level. An examination of the graphs leads to the belief that turbidity levels for the Masso River often exceeds the turbidity in Asan River.

The primary interest of the turbidity exceedance, however, is in comparing the relative impacts of the sediment reaching the reef from the two watershed areas. In order to determine the relative measure of sediment load in the Masso and Asan Rivers, the following assumptions were made. First, turbidity is a relative measure of sediment load at a given point. Secondly, turbidity multiplied by the stream flow is defined as a flux rate (turbidity * flow $=$ flux rate). In order to compare the two watersheds, the flux rate was divided by the watershed areas to produce an area weighted flux rate. Figure 10 illustrates the results of this measurement. Figure 10 takes into account both the amount of flow observed during turbidity measurements and relative sizes of the watershed by factoring watershed area. The product of this is an estimate of the frequency at which the relative sediment load $\left(\mathrm{NTU}{ }^{*} \mathrm{gpm} / \mathrm{mi}^{2}\right.$ ) exceeds a given value. The trends expressed by the relative sediment load duration curve seem to follow closely with the results of Figure 9. The median value of the relative sediment load is about $2000 \mathrm{NTU}^{*} \mathrm{gpm} / \mathrm{mi}^{2}$ for Masso River and $1140 \mathrm{NTU}^{*} \mathrm{gpm} / \mathrm{mi}^{2}$ for the Asan River (Figure 9). The average relative sediment load is 11646 $\mathrm{NTU}^{*} \mathrm{gpm} / \mathrm{mi}^{2}$ for Masso River and $11201 \mathrm{NTU}{ }^{*} \mathrm{gpm} / \mathrm{mi}^{2}$ for Asan River.

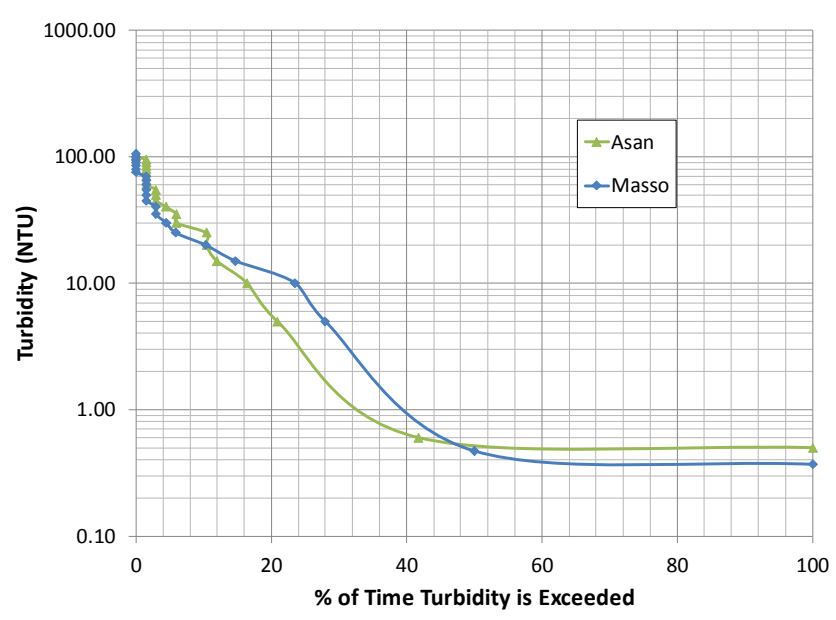

Figure 9. Turbidity duration for Masso and Asan river.

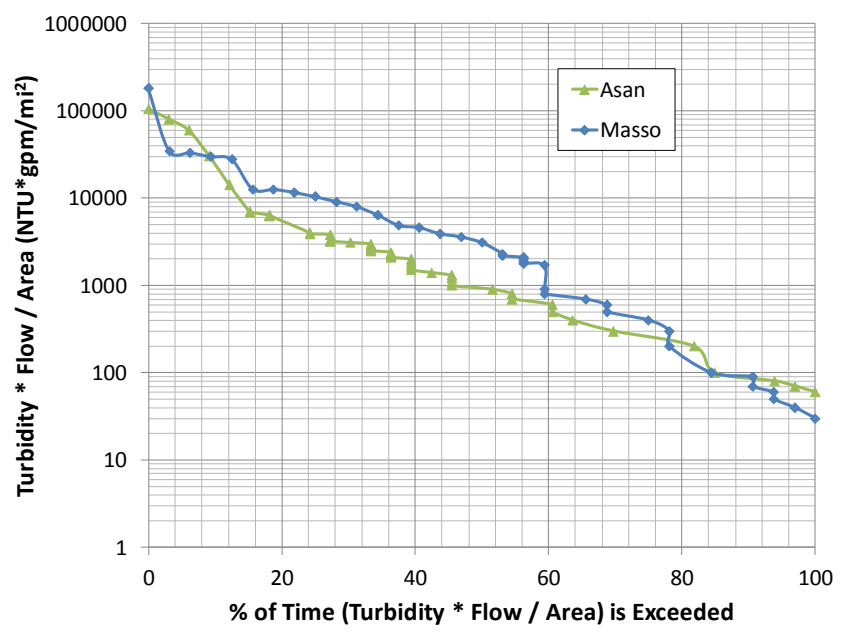

Figure 10. Relative sediment load duration curve for Piti and Asan Watersheds.

The lower level of turbidity shown in Figure 9 and 10 is influenced by the presence of the Masso Reservoir which is located less than a mile upstream from the Masso study site. Because of the reservoir's position downstream of most of the watershed area, much of the sediment is trapped and settled to the bottom of the reservoir before reaching the Masso study site during low rainfall events. During high rainfall events that cause more erosion however, the sediment carried by higher amounts of rainfall is not given time to settle in the reservoir before being carried to the study site and the river outlet.

A comparison of the measured flow and the areaadjusted turbidity for the Masso and Asan Rivers (Figure 11) shows that the Asan River is more reactive to changes in flow so that more turbidity per watershed area is produced by increases in stream flow than the Masso River. The turbidity measured within the Asan and Masso rivers (Figure 11) both reflect low overall turbidity levels, with the exception of major storm events, which produced large increases in the stream turbidity. This is caused by increased upland erosion during heavy rainfall events.

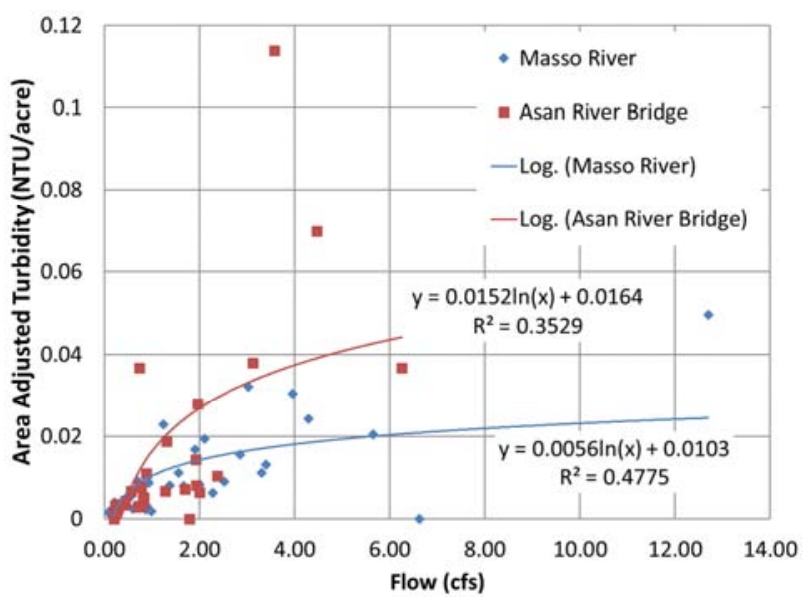

Figure 11. Flow versus Turbidity per Watershed Area of Asan and Masso Rivers. 


\subsection{Development of a Stage Discharge Curve for the Asan and Masso Rivers}

A preliminary stage discharge curve was developed for the Masso River (Figure 12) and the Asan River (Figure 13), which are the two major stream outlets for the Piti-Asan Watershed. The stage discharge curve was developed from the weekly stream flow measurements conducted within the Masso and Asan Rivers and the stream level measured by the installed level loggers.

It should be noted that an accurate stage discharge curve should utilize several years' worth of water level and stream flow data. The development of an accurate stage discharge curve for the primary rivers of the watershed is essential to future management of the watershed because the stage discharge curve removes the need for the weekly flow measurements of the watershed by providing a measurement of flow level in the river.

The stage discharge curves developed for this study utilized only one-year of data collected. Therefore, this does not provide a fully accurate estimate of the flow and water level relationship of the Masso and Asan Rivers. However, the stage discharge curve developed can serve as the basis for future hydrologic studies within the Piti-Asan Watershed. It is recommended that flow and level recordings of the Asan and Masso Rivers continue to be measured in order to obtain a more accurate estimate of the watershed behavior for future studies.

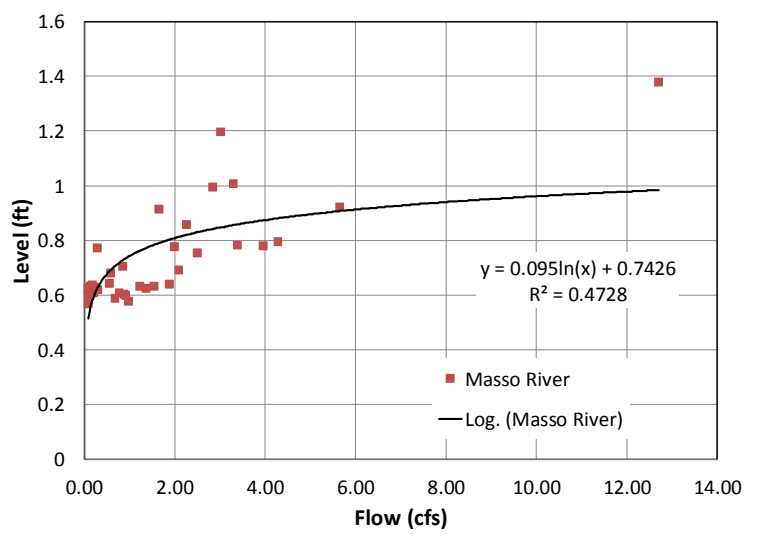

Figure 12. Masso River Stage Discharge Curve.

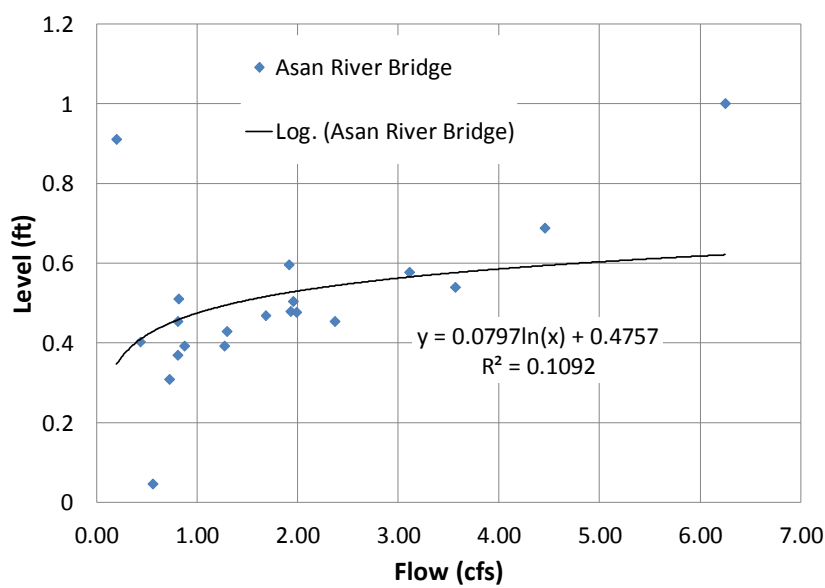

Figure 13. Asan River Stage Discharge Curve.

This watershed management tool will provide an estimate of flow based on measured stream levels.

\subsection{Soil Composite Testing Results}

The analyses of the composite soil test results (Table 1) indicated that all samples had relatively low $\mathrm{pH}$ levels and very low organic matter as compared to the soil reference for Guam developed by the University of Guam (UOG) Cooperative Extension Service [16] and which was referenced as the ideal soil values. This indicates that the soils are unable to sustain crops or large vegetation but instead can be prone to weedy species growth or bare soil. All of the soil composites also contained high levels of soluble magnesium $(\mathrm{Mg})$, which was likely increased by the soil acidity. The large amount of magnesium can act as an indicator of soil toxicity and can also indicate high levels of aluminum in the soil, which is toxic to animals and most plant species [17].

Most of the soils contained normal amounts of absorbable potassium $(\mathrm{K})$. The soils samples also contained little to no absorbable phosphorus (P), which was unusual for the high acidity of the soils. The majority of the soil composites are sandy clays and sandy clay loams. As such most of the soils have lower water retaining capacities and could be more prone to soil erosion during heavy rainfall [13].

Table 1. Soil composite test results.

\begin{tabular}{|c|c|c|c|c|c|c|c|c|c|}
\hline & Site & Avg. pH & Color & $\%$ OM & Soil Texture & K ppm & Ca ppm & Mg ppm & P ppm \\
\hline \multirow{9}{*}{ Masso } & 1 & 5.68 & $2.5 \mathrm{Y} 6 / 2$ & 2.17 & Sandy Clay & 144 & 10326 & 3126 & ND \\
\hline & 2 & 5.65 & $2.5 \mathrm{Y} 6 / 2$ & 2.20 & Sandy Clay Loam & 146 & 17493 & 2563 & 0.473 \\
\hline & 3 & 6.19 & 7.5YR 5/4 & 2.76 & Sandy Clay to Clay & 113 & 22370 & 1339 & 0.314 \\
\hline & 4 & 6.20 & 7.5YR $6 / 4$ & 1.55 & Clay & 81 & 13316 & 1566 & 1.279 \\
\hline & 5 & 6.11 & $2.5 Y 5 / 2$ & 1.46 & Sandy Clay Loam & 71 & 14416 & 3201 & ND \\
\hline & 6 & 6.02 & $2.5 \mathrm{Y} 5 / 2$ & 1.08 & Sandy Clay Loam & 99 & 6140 & 3146 & ND \\
\hline & 7 & 5.29 & 10YR 6/3 & 2.25 & Sandy Clay & 79 & 3775 & 6108 & ND \\
\hline & 9 & 5.09 & $5 Y R 6 / 4$ & 0.04 & Sandy Clay Loam & 91 & 1892 & 3105 & ND \\
\hline & 10 & 5.18 & $5 Y R 6 / 6$ & 0.92 & Sandy Clay Loam & 171 & 3181 & 3440 & ND \\
\hline \multirow{3}{*}{ Asan } & 11 & 5.90 & $5 Y R 6 / 6$ & 0.04 & Sandy Clay & 79 & 2579 & 319 & ND \\
\hline & 12 & 6.03 & 10YR 7/3 & 0.96 & Sandy Clay Loam & 63 & 5800 & 5206 & ND \\
\hline & 13 & 5.90 & 10 YR $5 / 2$ & 2.84 & Sandy Clay & 109 & 4525 & 5787 & ND \\
\hline
\end{tabular}




\begin{tabular}{llllllllll}
\hline & Site & Avg. $\mathbf{p H}$ & Color & \% OM & Soil Texture & K ppm & Ca ppm & Mg ppm & P ppm \\
\hline & 14 & 5.65 & 2.5 YR 5/4 & 0.13 & Clay Loam & 83 & 407 & 7519 & ND \\
& 15 & 5.62 & 10YR 5/2 & 3.50 & Sandy Clay Loam & 70 & 6050 & 2868 & ND \\
& 16 & 5.42 & 10 YR 6/3 & 2.23 & Sandy Clay Loam & 76 & 1698 & 5992 & ND \\
& 17 & 5.28 & 5 YR 6/4 & 0.20 & Sandy Clay Loam & 69 & 3015 & 1291 & ND \\
Ideal $^{*}$ & & 6.5 & & 8 & & 140 & 1500 & 150 & 50 \\
\hline
\end{tabular}

$\mathrm{ND}=$ Not Detected

*Ideal values adopted from [16].

\subsection{Estimated Annual Soil Loss}

The estimated soil loss from the Piti and Asan watersheds (Figure 14) were calculated from the erosion model developed by [10] using file layers at a resolution of $1 \mathrm{~m}^{2}$. The estimated soil loss from the Asan watershed was 8.05 ton/acre/year and 5.15 tons/acre/year for the Piti watershed.



Figure 14. Estimated soil loss for the Piti-Asan watershed.

There are five named rivers and two unnamed tributaries located within the watershed (Figure 14). The two primary rivers flowing through the watershed as mentioned earlier are the Masso river in Piti and the Asan river in Asan. A 100-meter buffer zone (Figure 15) around the rivers feeding in to the Asan Bay and Piti Bay was created using the ArcGIS buffer tool. This buffer zone was used to estimate the amount of soil that has the potential to be deposited into the two bays because erosive sites located further away from river bodies can be less likely to deposit soil into water bodies as deposition sites. The estimated soil loss of the buffered 100-meter area within the Piti-Asan watershed (Figure 15) is 4.57 tons/acre/year for Piti and 5.93 tons/acre/year for Asan.

Using the 100-meter buffer as a mask for the potential soil erosion from the Piti- Asan watershed, the raster was clipped to display only the potential soil erosion from within 100 meters of nearby streams and rivers (Figure 15). The potential contribution of sediment from within the buffered area to the river outlet in the Piti and Asan Bays is the primary focus of the sites in which recommendations are provided for erosion management practices in the watershed.

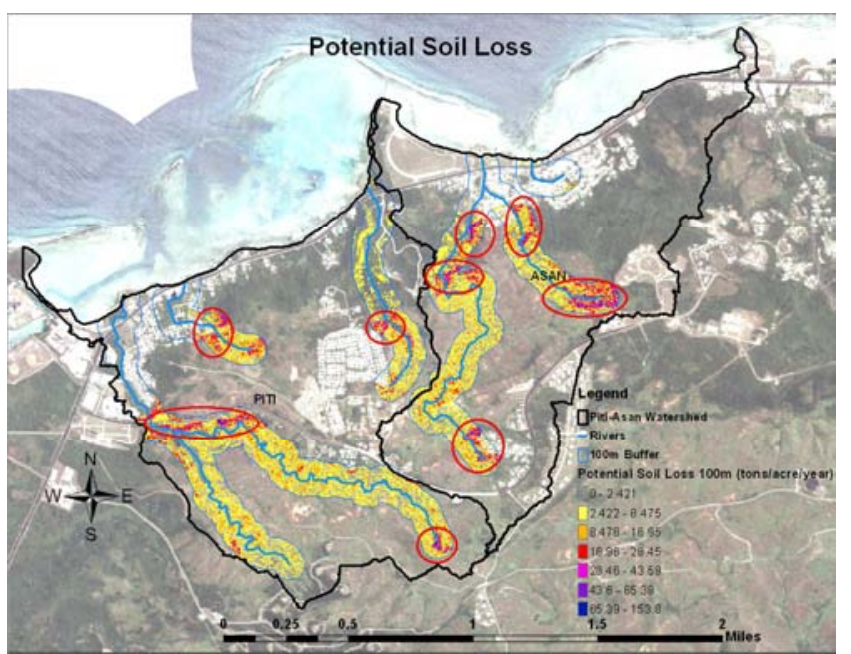

Figure 15. Estimated Soil Loss for Piti-Asan watershed within 100m of rivers along with high sedimentation contribution areas marked by red circles.

\section{Discussion on Watershed Management Practices}

Aerial and field observations show that the major contributors of soil erosion within the Piti-Asan watershed are both natural and human activity. Natural causes of soil erosion include highly erosive soils, poor vegetative soil protection, steep slopes, bank erosion, and heavy rainfall events. Human contributors include construction activities and the lack of erosion controls surrounding existing buildings, especially buildings along steep slopes. Areas identified to contribute high potential erosion, especially sites within the 100-meter buffer zone, should be prioritized and monitored. For future studies in the watershed it is also recommended that stream level and flow measurements continue to be collected in order to build upon the stage discharge curves created for the Masso and Asan Rivers.

An increase in the accuracy for future use of the GIS erosion model would also benefit from a more detailed vegetation map illustrating the dominant species of vegetation covering the site. This could be especially beneficial for high swordgrass (Miscanthus floridulus) covered areas, which can be more erosive than most other grass types and provide very little surface cover. As such the presence of high swordgrass may underestimate the potential soil loss in that area.

Slope stabilization using grass seeding, erosion blankets, or other slope stabilization methods to stabilize eroding sites, 
especially within 100 meters of river bodies, would minimize soil loss near river bodies. Furthermore, stringent policies and enforcement of erosion control methods in construction and development, especially along river bodies could minimize water pollution contributed to water bodies during and after construction. Construction occurring within the watershed, especially near water bodies should be conducting erosion and sedimentation control (ESC) practices throughout the duration of construction projects. Some recommended construction practices include the proper use of silt fencing, compost socks, berms, swales, vetiver hedge rows, or temporary sediment traps. Finally, stabilization of the mouth of the river bodies is also recommended to reduce erosion at river outlets.

\section{Conclusions}

This study analyzed the hydrologic behavior of the PitiAsan watershed in Guam through measurements of rainfall, stream level, stream flow, and river turbidity over the course of one year. Estimates of erosion contribution by areas within the watershed were conducted using the GIS erosion model developed by Park [10].

A correlation between the collected hydrologic data was made. The product of the research was a stage discharge curve for the Masso and Asan rivers. The study determined the areas contributing the most potential erosion and the major causes of soil erosion in the Piti-Asan Watershed. Such causes of erosion included: erosive soils, poor vegetative soil cover, bank erosion, steep slopes, heavy rainfall events, improperly managed construction, and lack of erosion management on existing buildings. Finally, management strategies to address these problems were suggested.

\section{Acknowledgements}

This research was funded by the National Oceanic and Atmospheric Administration (NOAA) through the Guam Coastal Management Program, Bureau of Statistics and Planning, Government of Guam Project no. CRI-GU-10 and the University of Guam's Water and Environmental Research Institute (WERI). Any conclusions made via this research does not reflect the opinion of the funding agencies and is based on author's research and analyses of data.

\section{References}

[1] UNCCD (2017). The global land outlook (GLO) report. UNCCD, 2017, First Edition: https://global-landoutlook.squarespace.com/the-outlook/\#the-bokk. United Nations Convention to Combat Desertification, p. 340.

[2] Houser DL, Pruess H. The effects of construction on water quality: a case study of the culverting of Abram Creek. Environmental monitoring and assessment. 2009 Aug 1;155(1-
4), pp.431-42.

[3] U. S. Department of the Interior Office of Surface Mining Reclamation and Enforcement. Environmental Assessment for the Freedom Mine West Mine Area. pp. 238, February 2016.

[4] Tecle A, and Neary D. Water Quality Impacts of Forest Fires. Journal of Pollution Effects and Control, 2015, 3(140). doi:10.4172/2375-4397.1000140.

[5] Minton D. Fire, Erosion, and Sedimentation in the Asan-Piti Watershed and War in the Pacific NHP, Guam. Technical Report 150, Pacific Cooperative Studies Unit, University of Hawaii at Manoa. November 2006.

[6] The Nature Conservancy (TNC). 2009. Draft Conservation Action Plan for Piti Bomb Holes Marine Preserve and Adjacent Watershed. Guam CAP Workshop. Hyatt Regency, Tumon, Guam. 6-7 August 2009.

[7] Manibusan S. The Hydrologic Response of the Piti-Asan Watershed to Development. University of Guam. Mangilao, Guam, MA thesis, October 2012.

[8] Kottermair, M. Piti-Asan watershed management plan. Technical Report \# 138, Water and Environmental Research Institute, University of Guam, 2012.

[9] Tsuda, R. T. and Donaldson, T. J. Cumulative and Secondary Impacts: Seawalker, Scuba Bob and the Fish Eye Underwater Observatory, Piti and Cocos Lagoon, Guam. Technical Report 108. University of Guam Marine Lab, Mangilao, GU. March 2004.

[10] Park MH. Developing a GIS-Based Soil Erosion Potential Model for the Ugum Watershed. MS Thesis, University of Guam. Mangilao, Guam, 2007.

[11] Young, F. J. A Soil Survey of the Territory of Guam. Soil Conservation Service, No. 16, United States Department of Agriculture (USDA), 1988.

[12] Page AL, Miller RH, Keeney DR. Methods of soil analysis. Part 2. Chemical and microbiological properties. Agronomy, No. 9. Soil Science Society of America, Madison, WI. 1982, p. 1159.

[13] Wischmeier WH, Smith DD. Predicting rainfall erosion losses-a guide to conservation planning. Predicting rainfall erosion losses-a guide to conservation planning. 1978.

[14] Khosrowpanah Sh, Heitz L, Wen Y, and Park M. 2007a. Developing a GIS-Based Soil Erosion Potential Model of the Ugum Watershed. Technical Report No. 117, Water and Environmental Research Institute, University of Guam. December 2007.

[15] Van Remortel RRM, and Hickey R. Computing the RUSLE LS Factor based on Array-based Slope Length Processing of Digital Elevation Data Using a C++ Executable. Computers and Geosciences, 2004, Volume 30. No. 9-10, pp. 1,0431,053 .

[16] University of Guam Cooperative Extension Service (UOG CES), 1980. Soil Analysis Recommendations Fact Sheet.

[17] Delhaize, Emmanuel, and Peter R. Ryan. Aluminum toxicity and tolerance in plants. Plant physiology, 107 (2), 1995, pp. 315-321. 